\title{
Case Report \\ Prenatal Virilization Associated with Paternal Testosterone Gel Therapy
}

\begin{abstract}
Anisha Patel and Scott A. Rivkees
Section of Pediatric Endocrinology, Department of Pediatrics, Yale Child Health Research Center, Yale University School of Medicine, 464 Congress Avenue, New Haven, CT 06520, USA

Correspondence should be addressed to Scott A. Rivkees, scott.rivkees@yale.edu

Received 26 July 2010; Accepted 27 September 2010

Academic Editor: Stuart A. Weinzimer

Copyright ( 92010 A. Patel and S. A. Rivkees. This is an open access article distributed under the Creative Commons Attribution License, which permits unrestricted use, distribution, and reproduction in any medium, provided the original work is properly cited.

Transdermal testosterone gels are used in the treatment of hypoandrogenism of males. Virilization due to exposure to testosterone gels has been reported in children resulting in a US Food and Drug Administration (FDA) warning about secondary exposure to these products. At present, we are unaware of prenatal virilization associated with unintentional testosterone gel exposure. We report prenatal virilization in a female infant due to secondary maternal exposure to the father's testosterone gel. We also describe postnatal virilization of the child's twin sister.
\end{abstract}

\section{Introduction}

Transdermal testosterone gels are used in the treatment of hypoandrogenism of males [1]. Virilization due to exposure to testosterone gels has been reported in children ranging from 9 months to 5 years of age [2-6]. In May 2009, the US Food and Drug Administration (FDA) issued a warning for testosterone gel products (AndroGel 1\% and Testim $1 \%$ ), alerting prescribers about secondary exposure to these products [7]. Based on interrogation of medical literature databases, at present we are unaware of prenatal virilization associated with unintentional testosterone gel exposure. We now report prenatal virilization of a female infant due to secondary maternal exposure to the father's testosterone gel. We also describe postnatal virilization of the child's twin sister.

\section{Case Presentation}

Dizygotic twin girls were born after a 30 -week gestation. Pregnancy was complicated by premature labor at 26 weeks of gestation requiring $12 \mathrm{mg}$ betamethasone treatment for two days. Medications taken during pregnancy were Wellbutrin, Pepcid, Procardia, and Indocin. The birth weight for Twin A was $1700 \mathrm{gm}$ and Twin B was $1660 \mathrm{gm}$.
Twin A required intubation and mechanical ventilation for 4 days followed by continuous positive airway pressure (CPAP) until day of life 8. Twin B required CPAP for 8 days. Both infants had apnea of prematurity and mild hyperbilirubinemia. The infants were discharged to home at 37 weeks post conception age.

At birth, Twin A was found to have clitoromegaly $(2.3 \times$ $1.7 \mathrm{~cm}$ ) [8] and was Prader Stage 2. Twin B did not have clitoromegaly $(0.3 \times 0.1 \mathrm{~cm})$. The urethral openings of the twins were at the base of the phallus.

At 96 hours of age, the total testosterone of the virilized twin was $9.8 \mathrm{ng} / \mathrm{dL}(0.4 \mathrm{nM})$, androstenedione was $71 \mathrm{ng} / \mathrm{dL}$ $(2 \mathrm{nM})$, and the 17-hydroxyprogesterone was $82 \mathrm{ng} / \mathrm{dL}$ $(2.4 \mathrm{nM})$ (Table 1; hormonal determinations performed at Esoterix Laboratory Services, Casablanca Hills, CA).

Transabdominal ultrasound showed normal Mullerian structures with no evidence of persistent Wolffian structures. The uterus measured $2.9 \times 0.67 \times 1.2 \mathrm{~cm}$ with normal endometrial stripe for age measuring of $0.6 \mathrm{~cm}$. The karyotype was 46, XX. An adrenocorticotropic hormone (ACTH) stimulation test yielded normal results at 10 days of age.

At 12 months of age, the circulating testosterone level was $103 \mathrm{ng} / \mathrm{dl}(4 \mathrm{nM})$. A pelvic ultrasound showed no adrenal or ovarian masses. An ACTH stimulation test revealed an elevated baseline testosterone level but no other abnormalities. 
TABle 1: Diagnostic test results for twin A.

\begin{tabular}{|c|c|c|c|c|c|c|c|c|c|c|}
\hline $\begin{array}{l}\text { Chronologic age } \\
\text { Twin A (months) }\end{array}$ & $\begin{array}{c}\text { Ref. } \\
\text { Range \# }\end{array}$ & 0.1 & 12 & 18 & 22 & $23^{*}$ & $25^{* *}$ & 29 & 34 & 38 \\
\hline $\begin{array}{l}\text { Total testosterone } \mathrm{ng} / \mathrm{dL} \\
(\mathrm{nM})\end{array}$ & $\begin{array}{c}<3-10 \\
(0.07-0.4) \\
\end{array}$ & $\begin{array}{c}9.8 \\
(0.4) \\
\end{array}$ & $\begin{array}{l}103 \\
(4) \\
\end{array}$ & $\begin{array}{c}46 \\
(1.8) \\
\end{array}$ & $\begin{array}{r}129 \\
(5.2) \\
\end{array}$ & $\begin{array}{c}115 \\
(4.8) \\
\end{array}$ & $\begin{array}{c}217 \\
(8.7) \\
\end{array}$ & $\begin{array}{c}4.6 \\
(0.18) \\
\end{array}$ & $\begin{array}{c}13 \\
(0.5) \\
\end{array}$ & $\begin{array}{c}2.3 \\
(0.09) \\
\end{array}$ \\
\hline $\begin{array}{l}\text { Androstenedione } \mathrm{ng} / \mathrm{dL} \\
(\mathrm{nM})\end{array}$ & $\begin{array}{c}<10-17 \\
(0.3-0.6) \\
\end{array}$ & $\begin{array}{c}71 \\
(2.0) \\
\end{array}$ & $\begin{array}{c}64 \\
(1.9) \\
\end{array}$ & $\begin{array}{c}46 \\
(1.4) \\
\end{array}$ & & & $\begin{array}{c}55 \\
(1.6) \\
\end{array}$ & $\begin{array}{c}<10 \\
(<0.03) \\
\end{array}$ & & \\
\hline $\begin{array}{l}\text { 17-Hydroxyprogesterone } \mathrm{ng} / \mathrm{dL} \\
(\mathrm{nM})\end{array}$ & $\begin{array}{c}3-90 \\
(0.1-3) \\
\end{array}$ & $\begin{array}{c}82 \\
(2.4) \\
\end{array}$ & $\begin{array}{c}17 \\
(0.5) \\
\end{array}$ & & $\begin{array}{c}15 \\
(0.45) \\
\end{array}$ & $\begin{array}{c}14 \\
(0.42) \\
\end{array}$ & & $\begin{array}{c}<10 \\
(<0.3) \\
\end{array}$ & & \\
\hline $\begin{array}{l}\text { 17-Hyroxypregnenolone } \\
\text { ng/dL (nM) }\end{array}$ & $\begin{array}{l}14-207 \\
(0.4-7) \\
\end{array}$ & & $\begin{array}{l}135 \\
(4) \\
\end{array}$ & & & & & & & \\
\hline $\begin{array}{l}\text { Dehydroepiandrosterone } \mathrm{ng} / \mathrm{dL} \\
(\mathrm{nM})\end{array}$ & $\begin{array}{l}20-130 \\
(0.6-4) \\
\end{array}$ & & $\begin{array}{c}20 \\
(0.6) \\
\end{array}$ & & $\begin{array}{c}47 \\
(1.4) \\
\end{array}$ & $\begin{array}{c}83 \\
(2.5) \\
\end{array}$ & & & & \\
\hline $\begin{array}{l}\text { 5-Dehydroepiandrosterone-sulfate } \\
\mathrm{mcg} / \mathrm{dL}\end{array}$ & $<5-57$ & & & 11 & & & $<10$ & 22 & & \\
\hline$(\mathrm{nM})$ & $(<0.1-1.4)$ & & & $(0.44)$ & & & $(<0.4)$ & $(0.88)$ & & \\
\hline $\begin{array}{l}\text { Cortisol ng/dL } \\
(\mathrm{nM})\end{array}$ & $\begin{array}{c}3-21 \\
(0.9-7) \\
\end{array}$ & & $\begin{array}{c}3 \\
(0.9) \\
\end{array}$ & & & & & & & \\
\hline $\begin{array}{l}\text { Renin } \mathrm{ng} / \mathrm{mL} / \mathrm{hr} \\
(<10)\end{array}$ & $1-6.5$ & & 6.0 & & & & & & & \\
\hline $\begin{array}{l}\text { Estradiol ng/dL } \\
(\mathrm{nM})\end{array}$ & $\begin{array}{l}<15 \\
(<0.4) \\
\end{array}$ & & & & $\begin{array}{c}<0.10 \\
(<0.003) \\
\end{array}$ & & & & & \\
\hline $\begin{array}{l}\text { Deoxycorticosterone } \mathrm{ng} / \mathrm{dL} \\
(\mathrm{nM})\end{array}$ & $\begin{array}{c}2-34 \\
(0.6-1.0) \\
\end{array}$ & & & & $\begin{array}{c}<2.0 \\
(<0.06) \\
\end{array}$ & & & & & \\
\hline $\begin{array}{l}\text { DHT ng/dL } \\
(\mathrm{nM})\end{array}$ & $\begin{array}{c}<3 \\
(<0.3) \\
\end{array}$ & & & & & & $\begin{array}{c}35 \\
(1.4) \\
\end{array}$ & & & \\
\hline Bone Age (mo) & & & 15 & 18 & 24 & & & & & 36 \\
\hline
\end{tabular}

\# Prepubertal reference ranges from Esoterix Laboratory Services, Casablanca Hills, CA.

* After $0.25 \mathrm{mg}$ of dexamethasone per day for 2 weeks.

**AndroGel exposure revealed at 25 months of age.

At 22 months, the testosterone level was $129 \mathrm{ng} / \mathrm{dl}(5 \mathrm{nM})$. An MRI showed normal adrenal gland and ovaries. A trial of dexamethasone was given to suppress potential adrenal gland androgen production ( $0.25 \mathrm{mg}$ per day for 2 weeks), but testosterone levels did not decrease $(155 \mathrm{ng} / \mathrm{dl} ; 6 \mathrm{nM})$.

At 25 months of age, Twin B presented with clitoromegaly and a few pubic hairs. The testosterone level was $50 \mathrm{ng} / \mathrm{dl}$ (2 nM) (Table 2). An ACTH stimulation test and adrenal pelvic ultrasound studies were normal. A bone age was the same as the chronological age.

Shortly thereafter, after not previously revealing usage, the father stated that he had been using AndroGel three times a day for several years. The gel was applied on the forearms, and he cradled the children when they slept in their parent's bed.

The father was advised about proper precautions in using AndroGel. At 29 months, testosterone levels had decreased to $4.6(0.16 \mathrm{nM})$ and $7.6 \mathrm{ng} / \mathrm{dl}(0.3 \mathrm{nM})$, respectively, in Twin $\mathrm{A}$ and B. At 34 months, testosterone levels increased to 13 $(0.5 \mathrm{nM})$ and $18.0 \mathrm{ng} / \mathrm{dl}(0.7 \mathrm{nM})$, respectively, in Twin A and B. It was recommended that AndroGel be discontinued in favor of parenteral administration.

At 36 months, the parents separated and the mother and children moved to a new residence. At 38 months, testosterone levels were $2.3(0.09 \mathrm{nM})$ and $3.1 \mathrm{ng} / \mathrm{dl}(0.09 \mathrm{nM})$, respectively, for Twin A and $\mathrm{B}$. Bone ages were the same as the chronological age.

\section{Discussion}

Testosterone products are used in the treatment of hypogonadism, which is associated with decreased libido, erectile dysfunction, reduced muscle mass, and reduced bone density $[1,9]$. It is estimated that about 4 million men suffer from this condition in the US, and [9] 1.8 million prescriptions are written for topical testosterone products annually [10].

When used in the household, children and women are at risk for secondary, unintentional testosterone gel exposure $[9,10]$. Enlargement of genitalia, precocious pubic hair development, bone age advancement, and inappropriate aggressive and sexual behavior have been reported in children with secondary testosterone gel exposure [26 ]. Although, some children have reversal of virilization following elimination of exposure, advance bone ages and clitoromegaly have been found to persist [2-6]. Of note, although the testosterone exposure was significant enough to induce virilization in both girls, it did not result in bone age advancement. These observations suggest that the genitalia are more sensitive to effects of testosterone exposure than the skeletal system. 
TABle 2: Diagnostic test results for twin B.

\begin{tabular}{|c|c|c|c|c|c|}
\hline $\begin{array}{l}\text { Chronologic age } \\
\text { Twin B (months) }\end{array}$ & $\begin{array}{c}\text { Ref. } \\
\text { Range \# }\end{array}$ & $25^{* *}$ & 29 & 34 & 38 \\
\hline $\begin{array}{l}\text { Total testosterone } \mathrm{ng} / \mathrm{dL} \\
(\mathrm{nM})\end{array}$ & $\begin{array}{c}<3-10 \\
(0.07-0.4)\end{array}$ & $\begin{array}{l}50 \\
(2)\end{array}$ & $\begin{array}{c}7.6 \\
(2.3)\end{array}$ & $\begin{array}{l}18.2 \\
(0.7)\end{array}$ & $\begin{array}{c}3.1 \\
(0.12)\end{array}$ \\
\hline $\begin{array}{l}\text { Androstenedione } \mathrm{ng} / \mathrm{dL} \\
(\mathrm{nM})\end{array}$ & $\begin{array}{c}<10-17 \\
(0.3-0.6)\end{array}$ & $\begin{array}{c}31 \\
(0.93)\end{array}$ & $\begin{array}{l}<10 \\
(0.3)\end{array}$ & & \\
\hline $\begin{array}{l}\text { 17-Hydroxyprogesterone } \mathrm{ng} / \mathrm{dL} \\
(\mathrm{nM})\end{array}$ & $\begin{array}{c}3-90 \\
(0.1-3) \\
\end{array}$ & $\begin{array}{c}14 \\
(0.42) \\
\end{array}$ & $\begin{array}{l}<10 \\
(0.3) \\
\end{array}$ & & \\
\hline $\begin{array}{l}\text { 5-Dehydroepiandrosterone-sulfate } \\
\mathrm{mcg} / \mathrm{dL} \\
(\mathrm{nM})\end{array}$ & $\begin{array}{c}<5-57 \\
(<0.1-1.4)\end{array}$ & $\begin{array}{c}20 \\
(0.8)\end{array}$ & $\begin{array}{c}21 \\
(0.84)\end{array}$ & & \\
\hline Bone Age (mo) & & 24 & & & 36 \\
\hline
\end{tabular}

\#Prepubertal reference ranges from Esoterix Laboratory Services, Casablanca Hills, CA.

**AndroGel exposure discovered at 25 months of age.

Secondary exposure of women to testosterone gels has been observed [10]. Women exposed to testosterone gel can show hirsutism, irregular menses, and mood changes [10]. The mother of the children in this report, though, did not manifest signs of androgen excess, including acne or hirsutism.

Support for the notion that bystander testosterone exposure resulted in prenatal and postnatal virilization comes from the exclusion of intrinsic causes of virilization. ACTH stimulation testing on two occasions was normal, dexamethasone did not suppress testosterone levels, and there was no structural ovarian or adrenal pathology. Most importantly there was reduction of testosterone levels in both girls when they moved to a new environment.

At present we are not aware of other cases of prenatal virilization associated with transdermal testosterone exposure. It is interesting that only one of the twins developed intrauterine clitoromegaly suggesting that individual differences in placental testosterone transmission or sensitivity to the hormone played a role here. This notion is supported by other studies showing variable female infant virilization born to women with androgen producing tumors or conditions [11-13].

Our observations suggest that transdermal testosterone exposure during pregnancy can result in virilization of the fetus. In addition to concerns about postnatal childhood secondary testosterone exposure, adverse effects on the fetus following maternal exposure need to be considered.

\section{References}

[1] S. Bhasin, G. R. Cunningham, F. J. Hayes et al., “Testosterone therapy in men with androgen deficiency syndromes: an Endocrine Society clinical practice guideline," Journal of Clinical Endocrinology and Metabolism, vol. 95, no. 6, pp. 2536-2559, 2010.

[2] S. K. Bhowmick, T. Ricke, and K. R. Rettig, "Sexual precocity in a 16-month-old boy induced by indirect topical exposure to testosterone," Clinical Pediatrics, vol. 46, no. 6, pp. 540-543, 2007.

[3] C. Brachet, J. Vermeulen, and C. Heinrichs, "Children's virilization and the use of a testosterone gel by their fathers,"
European Journal of Pediatrics, vol. 164, no. 10, pp. 646-647, 2005.

[4] E. Cohen, O. M. Navarro, E. Reynolds, R. P. Schwartz, and P. Venkataramani, "Index of suspicion," Pediatrics in Review, vol. 28, pp. 419-425, 2007.

[5] G. J. Kunz, K. O. Klein, R. D. Clemons, M. E. Gottschalk, and K. L. Jones, "Virilization of young children after topical androgen use by their parents," Pediatrics, vol. 114, no. 1, pp. 282-284, 2004.

[6] Y. M. Yu, N. Punyasavatsu, D. Elder, and A. J. D'Ercole, "Sexual development in a two-year-old boy induced by topical exposure to testosterone," Pediatrics, vol. 104, no. 2, p. e23, 1999.

[7] US Food and Drug Administration, "Testosterone gel products (AndroGel 1\% and Testim 1\%)," 2009, http://www.fda.gov/ Safety/MedWatch/SafetyInformation/SafetyAlertsforHumanMedicalProducts/ucm 149346.htm.

[8] K. Sane and O. Hirsch Pescovitch, "The clitoral index: a determination of clitoral size in normal girls and girls with abnormal sexual development," Journal of Pediatrics, vol. 120, no. 2, pp. 264-266, 1992.

[9] E. L. Rhoden and A. Morgentaler, "Risks of testosteronereplacement therapy and recommendations for monitoring," New England Journal of Medicine, vol. 350, no. 5, pp. 482-492, 2004.

[10] W. de Ronde, "Hyperandrogenism after transfer of topical testosterone gel: case report and review of published and unpublished studies," Human Reproduction, vol. 24, no. 2, pp. 425-428, 2009.

[11] Y.-C. Wang, H.-Y. Su, J.-Y. Liu, F.-W. Chang, and C.-H. Chen, "Maternal and female fetal virilization caused by pregnancy luteomas," Fertility and Sterility, vol. 84, no. 2, pp. 509.e15509.e17, 2005.

[12] R. Bertalan, L. Csabay, A. Blazovics et al., "Maternal hyperandrogenism beginning from early pregnancy and progressing until delivery does not produce virilization of a female newborn," Gynecological Endocrinology, vol. 23, no. 10, pp. 581-583, 2007.

[13] H. Ugaki, T. Enomoto, Y. Tokugawa, and T. Kimura, "Luteoma-induced fetal virilization," Journal of Obstetrics and Gynaecology Research, vol. 35, no. 5, pp. 991-993, 2009. 